\title{
CRITICAL LOADS OF SULPHUR AND NITROGEN FOR TERRESTRIAL ECOSYSTEMS IN LITHUANIA
}

\author{
V. Ulevičius, S. Byčenkienè, and K. Senuta \\ Institute of Physics, Savanoriu 231, LT-02300 Vilnius, Lithuania \\ E-mail: ulevicv@ktl.mii.lt
}

Received 8 January 2009; accepted 19 March 2009

\begin{abstract}
This paper presents the deposition variation of sulphur and nitrogen compounds and the exceedance of their critical loads for terrestrial ecosystems. The analysis is based on a steady-state approach, involving the comparison of deposition fluxes with critical loads to identify areas where critical loads are exceeded. The critical load concept is widely used as a tool for developing emission control policies in Europe. Critical loads for acidity, nitrogen, and sulphur have been calculated for Lithuania as a signatory country of the Convention of Long-Range Transboundary Air Pollution. In addition, the comparison of sulphur deposition with critical loads for eutrophication yielded an exceedance in southern, southeastern, southwestern, and central parts of Lithuanian ecosystems. Deposition of sulphur as well as oxidized and reduced nitrogen from anthropogenic sources remains low over the central and some northern part of the country but are significant in eastern areas.
\end{abstract}

Keywords: nitrogen, sulphur, critical loads, deposition, ecosystems, mass balance method

PACS: 91.62.Mn, 92.20.jp

\section{Introduction}

Acid deposition and air quality are areas of concern for policymakers, forestry experts, air quality divisions and there is a need to make informed decisions regarding emission controls. In order to control emissions, international cooperation is deemed indispensable, and for that purpose, the United Nations Economic Commission for Europe (UNECE) Convention on LongRange Transboundary Air Pollution (LRTAP) was established in 1979 [1]. Today, the LRTAP Convention has fifty-one parties, forty-seven of which are European. There is no directive to monitor the air emissions and to prepare the air emission inventories for the LRTAP Convention. The Convention, through its binding protocols covering the main air pollutants, has contributed to significant reductions in emissions of air pollutants in the ECE region. In addition to the UN Protocols, several European Union (EU) Directives are regulating emissions, the most recent one being the $2001 \mathrm{Na}-$ tional Emission Ceilings (NEC) Directive, 2001/81/EC [2]. The NEC Directive establishes emission ceilings to be attained by 2010 for sulphur dioxide $\left(\mathrm{SO}_{2}\right)$, nitrogen oxides $\left(\mathrm{NO}_{x}\right)$, volatile organic compounds (VOCs), and ammonia $\left(\mathrm{NH}_{3}\right)$ for $25 \mathrm{EU}$ Member States. Lithuania as a European Union member state also has annual obligations under the Directive 2001/81/EC of the Eu- ropean Parliament and of the Council on national emission ceilings for certain atmospheric pollutants (NEC Directive), which requires preparing and annually updating national emission inventory for the abovementioned air pollutants. The critical load concept has been developed in Europe since the mid-1980s, mostly under the auspices of the 1979 Convention on Long-Range Transboundary Air Polution. European databases and maps of critical loads have been instrumental in formulating effects-based Protocols to the LRTAP Convention, such as the 1994 Protocol on Further Reduction of Sulphur Emissions and the 1999 Protocol to Abate Acidification, Eutrophication and Ground-level Ozone (the "Gothenburg Protocol").

Man-made sulphur dioxide $\left(\mathrm{SO}_{2}\right)$ results from the combustion of sulphur-containing fossil fuels (principally coal and heavy oils) and the smelting of sulphur containing ores. After being released in the atmosphere, $\mathrm{SO}_{2}$ is further oxidized to sulphate and sulphuric acid forming an aerosol often associated with other pollutants in droplets or solid particles extending over a wide range of sizes. $\mathrm{SO}_{2}$ and its oxidation products are removed from the atmosphere by wet and dry deposition. Volcanoes and oceans are the major natural sources of $\mathrm{SO}_{2}$. Natural fluxes of sulphur originate from volcanoes as well as biological and photochemical 
production of volatile sulphur gases, notably dimethyl sulphide (DMS) in oceans. Comparably small amounts of sulphur are also emitted from forest fires, soils, and vegetation and sea salt [3]. These sources were estimated to contribute only around $2 \%$ of the total emissions of sulphur dioxide in the European Monitoring and Evaluation Programme (EMEP) area [4].

The input of nitrogen to ecosystems has increased dramatically over past decades. European emissions of nitrogen oxides arise mainly from anthropogenic combustion sources, where NO is formed by reaction between nitrogen and oxygen in the combustion air and to some extent by oxidation of nitrogen in fuel. The amounts formed depend on the pressure and temperature of the combustion process. Small amounts of $\mathrm{NO}_{2}$ $(<10 \%)$ are emitted directly during combustion. Natural nitrogen oxide emissions from soil, volcanoes, and lightning are important on the global scale, but account for a small part $(<10 \%)$ of total European emissions. $\mathrm{NO}_{x}$ emissions from stationary sources have decreased in many areas, while the emissions from vehicles have increased due to the fact that growth in the number of vehicles is much larger than the decrease in emissions [5]. Nitrogen compounds are present in the atmosphere in both oxidized and reduced forms. The reduced compounds include ammonia $\left(\mathrm{NH}_{3}\right)$ and ammonium $\left(\mathrm{NH}_{4}\right)$. The oxidized compounds include nitrous oxide $\left(\mathrm{N}_{2} \mathrm{O}\right)$, nitrogen oxide $(\mathrm{NO})$, nitrogen dioxide $\left(\mathrm{NO}_{2}\right)$, nitrous acid $\left(\mathrm{HNO}_{2}\right)$, nitric acid $\left(\mathrm{HNO}_{3}\right)$, peroxyacetylnitrate (PAN), and particulate nitrate $\left(\mathrm{NO}_{3}\right) . \mathrm{NO}_{x}$ is defined as $\mathrm{NO}+\mathrm{NO}_{2}$. The deposition of atmospheric nitrogen compounds occurs via dry and wet processes.

Industrial, agricultural, and other anthropogenic activities have greatly modified the global biogeochemical cycles of nitrogen and sulphur. The current human disruption of both cycles, however, leads to deposition rates far in excess of natural ones. Several environmental problems are related to disturbance of $\mathrm{S}$ and $\mathrm{N}$ cycles: these include acidification and eutrophication of soils and water $[6,7]$.

Combustion of fossil fuels emits sulphur and nitrogen dioxides into the atmosphere where gases are converted into acids, which, after deposition, lead to a series of undesired changes in terrestrial and aquatic ecosystems. Acidification of soils gives rise to indirect impacts associated with the cumulative impact of wet and dry sulfur and nitrogen deposition. In the last 30 years acidification has become perceived as a major environmental issue, due to the obvious forest decline in parts of Scandinavia and Central Europe [8]. Mean nitrogen throughfall deposition ranged from 9.1 to $11.0 \mathrm{~kg} \mathrm{ha}^{-1} \mathrm{yr}^{-1}$ measured in $2000-2005$ for about 220 plots in Europe. The nitrate deposition ranged from 4.6 to $5.7 \mathrm{~kg} \mathrm{ha}^{-1} \mathrm{yr}^{-1}$. Mean throughfall sulphate inputs decreased from 7.8 to $5.9 \mathrm{~kg} \mathrm{ha}^{-1} \mathrm{yr}^{-1}$ in the $2000-2005$ period. $23 \%$ of the plots showed significantly decreasing sulphur inputs, whereas only one plot showed an increase. The comparatively low sulphate throughfall deposition was measured in the Alpine region, Scandinavia, and the Iberian Peninsula. The mean bulk sulphate deposition decreased continuously from 6.1 in 2000 to $4.4 \mathrm{~kg} \mathrm{Sha}^{-1} \mathrm{yr}^{-1}$ in 2003 and reached $4.6 \mathrm{~kg} \mathrm{Sha}^{-1} \mathrm{yr}^{-1}$ in 2005.

Several environmental problems are directly caused by the disturbance of $\mathrm{S}$ and $\mathrm{N}$ cycles. Large-scale acidification of soils and water was identified as an important environmental problem in North America and Europe about thirty years ago. More recently, acidification has also been recognized as a potential threat to ecosystems in other parts of the world [9].

Currently, $11 \%$ of the world's natural vegetation receives nitrogen deposition in excess of the "critical load" (CL) threshold of $10 \mathrm{~kg} \mathrm{~N} \mathrm{ha}^{-1} \mathrm{yr}^{-1}$. The most affected regions are the United States (20\% of vegetation), western Europe (30\%), eastern Europe (80\%), South Asia (60\%), East Asia (40\%), Southeast Asia (30\%), and Japan (50\%). Future deposition fluxes are mainly driven by changes in emissions, and less importantly by changes in atmospheric chemistry and climate [10].

Since the attention was drawn to the effects of "acid rain" on forest die back in the 1980s, atmospheric deposition was an important international scientific topic of interest. An important concept is the critical load of chemical compounds of sulphur and nitrogen. Critical load is defined as a quantitative estimate of an exposure to one or more pollutants below which significant harmful effects on specified sensitive elements of the environment do not occur according to the present knowledge. Since then, several methods have been developed to estimate the critical loads per ecosystem [11]. In the procedures developed within LRTAP two types of critical loads are being used: (i) critical loads based on soil properties and steady-state mass balance methods and (ii) empirical critical loads (eCLs) based on scientific knowledge of effects of nitrogen enrichment on ecosystems. The output of the mapping procedure is the digital and graphic representation of total annual deposition fluxes of air pollutants (sulphur and nitrogen) into ecosystems within the national boundaries of Lithuania. The deposition maps show actual deposition rates from the atmosphere to the landscape surface at a high spatial resolution, taking into account the distribution 
of specific ecosystems derived from the CORINE land use database CLC2000-LT. The soil map of Lithuania and long-term data of precipitation together with Geographic Information Systems (GIS) software were overlaid on one another.

Until the year 2004 the emission inventory was compiled by Air Division specialists, Environmental Quality Department, Ministry of Environment. The air emission inventory for 2000 and 2004-2007 was prepared by the expert team from the Institute of Physics in co-operation with Air Division specialists, Ministry of Environment.

The objective of the study was to estimate the critical loads of nitrogen and sulphur compounds in Lithuania.

\section{Methods}

The starting point for calculating critical loads of nutrient $N$ by the SMB (Simple Mass Balance) model is the mass balance of total nitrogen for the soil compartment under consideration (inputs $=$ sinks + outputs):

$$
\begin{aligned}
\mathrm{N}_{\text {dep }}+\mathrm{N}_{\text {fix }}= & \mathrm{N}_{\mathrm{ad}}+\mathrm{N}_{\mathrm{i}}+\mathrm{N}_{\mathrm{u}}+\mathrm{N}_{\mathrm{de}} \\
& +\mathrm{N}_{\text {eros }}+\mathrm{N}_{\text {fire }}+\mathrm{N}_{\mathrm{vol}}+\mathrm{N}_{\mathrm{le}}
\end{aligned}
$$

where $\mathrm{N}_{\text {dep }}$ is the total $\mathrm{N}$ deposition, $\mathrm{N}_{\text {fix }}$ is the $\mathrm{N}$ "input" by biological fixation, $\mathrm{N}_{\mathrm{ad}}$ is $\mathrm{N}$ adsorption, $\mathrm{N}_{\mathrm{i}}$ is the long-term net immobilization of $\mathrm{N}$ in soil organic matter, $\mathrm{N}_{\mathrm{u}}$ is the net removal of $\mathrm{N}$ harvested vegetation and animals, $\mathrm{N}_{\mathrm{de}}$ is flux of $\mathrm{N}$ to the atmosphere due to denitrification, $\mathrm{N}_{\text {eros }}$ are $\mathrm{N}$ losses through erosion, $\mathrm{N}_{\text {fire }}$ are $\mathrm{N}$ losses in smoke due to (wild or controlled) fires to the atmosphere, $\mathrm{N}_{\mathrm{vol}}$ are $\mathrm{N}$ losses to the atmosphere via $\mathrm{NH}_{3}$ volatilization, and $\mathrm{N}_{\mathrm{le}}$ is leaching of $\mathrm{N}$ below the root zone.

The following assumptions lead to a simplification of Eq. (1): nitrogen adsorption, e.g., the adsorption of $\mathrm{NH}_{4}$ by clay minerals, can temporarily lead to an accumulation of $\mathrm{N}$ in the soil, however it is stored / released only when the deposition changes, and can thus be neglected in steady-state considerations; nitrogen fixation is negligible in most (forest) ecosystems, except for $\mathrm{N}$-fixing species; the loss of $\mathrm{N}$ due to fires, erosion, and volatilization is small for most ecosystems in Europe, and therefore neglected. Alternatively, one could replace $\mathrm{N}_{\mathrm{i}}$ by $\mathrm{N}_{\mathrm{i}}+\mathrm{N}_{\text {eros }}+\mathrm{N}_{\text {fire }}+\mathrm{N}_{\mathrm{vol}}-\mathrm{N}_{\text {fix }}$ in the subsequent equations. The leaching of ammonium $\left(\mathrm{NH}_{4}\right)$ can be neglected in all forest ecosystems due to (preferential) uptake and complete nitrification within the root zone (i. e., $\mathrm{NH}_{4, \mathrm{le}}=0, \mathrm{~N}_{\mathrm{le}}=\mathrm{NO}_{3, \mathrm{le}}$ ). Under these simplifying assumptions Eq. (1) becomes

$$
\mathrm{N}_{\text {dep }}=\mathrm{N}_{\mathrm{i}}+\mathrm{N}_{\mathrm{u}}+\mathrm{N}_{\mathrm{de}}+\mathrm{N}_{\mathrm{le}} .
$$

From this equation a critical load is obtained by defining an acceptable limit to the leaching of $\mathrm{N}$, $\mathrm{N}_{\mathrm{le} \text { (acc) }}$, the choice of this limit depending on the "sensitive element of the environment" to be protected. When an acceptable leaching is inserted into Eq. (2), the deposition of $\mathrm{N}$ becomes the critical load of nutrient nitrogen, $\mathrm{CL}_{\text {nut }}(\mathrm{N})$ :

$$
\mathrm{CL}_{\text {nut }}(\mathrm{N})=\mathrm{N}_{\mathrm{i}}+\mathrm{N}_{\mathrm{u}}+\mathrm{N}_{\mathrm{de}}+\mathrm{N}_{\mathrm{le}(\text { acc })} .
$$

In deriving the critical load of nutrient $\mathrm{N}$ in Eq. (3), it is assumed that the sources and sinks do not depend on the deposition of $\mathrm{N}$. This is unlikely to be the case and thus all quantities should be taken "at critical load". However, to compute, e. g., "denitrification at critical load" one needs to know the CL, the very quantity one wants to compute. The only clean way to avoid this circular reasoning is to establish a functional relationship between deposition and the sink of $\mathrm{N}$, insert this function into Eq. (2), and solve for the deposition (to obtain the critical load). This has been done for denitrification: in the simplest case denitrification is linearly related to the net input of $\mathrm{N}[12,13]$ :

$$
\mathrm{N}_{\mathrm{de}}=\left\{\begin{array}{cc}
f_{\mathrm{de}} \cdot\left(\mathrm{N}_{\mathrm{dep}}-\mathrm{N}_{\mathrm{i}}-\mathrm{N}_{\mathrm{u}}\right) & \text { if } \mathrm{N}_{\mathrm{dep}}>\mathrm{N}_{\mathrm{i}}+\mathrm{N}_{\mathrm{u}}, \\
0 & \text { otherwise, }
\end{array}\right.
$$

where $f_{\mathrm{de}}\left(0 \leq f_{\mathrm{de}}<1\right)$ is the so-called denitrification fraction, a site-specific quantity. This formulation implicitly assumes that immobilization and uptake are faster processes than denitrification. Inserting this expression for $\mathrm{N}_{\mathrm{de}}$ into Eq. (2) and solving for the deposition lead to the following expression for the critical load of nutrient $\mathrm{N}$ :

$$
\mathrm{CL}_{\mathrm{nut}}(\mathrm{N})=\mathrm{N}_{\mathrm{i}}+\mathrm{N}_{\mathrm{u}}+\frac{\mathrm{N}_{\mathrm{le}(\mathrm{acc})}}{1-f_{\mathrm{de}}}
$$

The acceptable $\mathrm{N}$ leaching (in eq $\mathrm{ha}^{-1} \mathrm{yr}^{-1}$ ) is calculated as

$$
\mathrm{N}_{\mathrm{le}(\mathrm{acc})}=\mathrm{Q} \cdot[\mathrm{N}]_{\mathrm{acc}},
$$

where $[\mathrm{N}]_{\text {acc }}$ is the acceptable $\mathrm{N}$ concentration $\left(\mathrm{eq} \mathrm{m}^{-3}\right)$ and $Q$ is the precipitation surplus (in $\mathrm{m}^{3} \mathrm{ha}^{-1} \mathrm{yr}^{-1}$ ). Values for acceptable $\mathrm{N}$ concentration are given in Table 1.

Dutch and Ineson [14] reviewed data on rates of denitrification [14]. Typical values of $\mathrm{N}_{\mathrm{de}}$ for boreal 


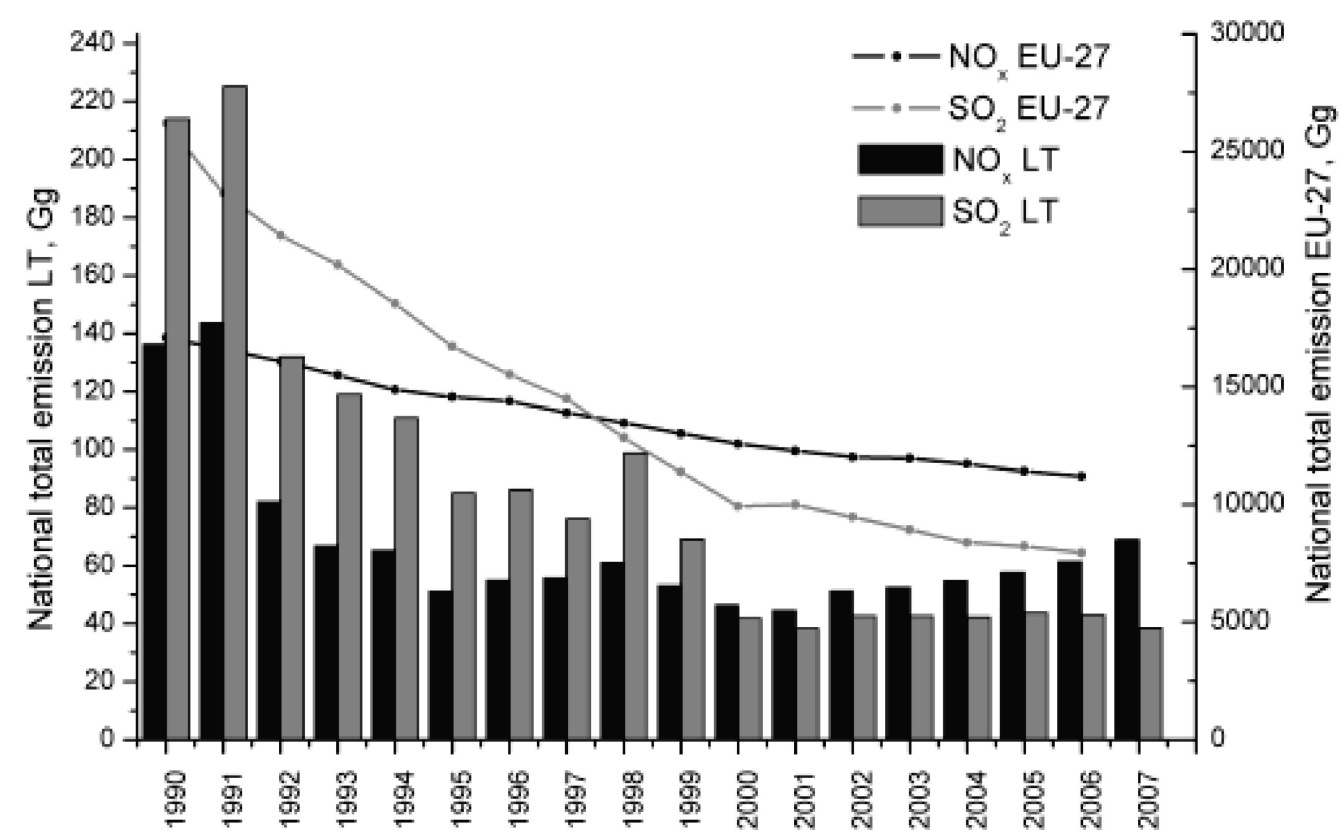

Fig. 1. $\mathrm{SO}_{2}$ and $\mathrm{NO}_{x}$ emission trend in Lithuania, 1990-2007 [15].

Table 1. Critical (acceptable) $\mathrm{N}$ concentrations in soil solution for calculating $\mathrm{CL}_{\text {nut }}(\mathrm{N})$ [11].

\begin{tabular}{lc}
\hline \multicolumn{1}{c}{ Impact } & {$[\mathrm{N}]_{\mathrm{acc}}, \mathrm{mg} \mathrm{N}^{-1}$} \\
\hline Vegetation changes (data established in the Netherlands) $^{1}:$ & \\
Coniferous forest & $2.5-4.0$ \\
Deciduous forest & $3.5-6.5$ \\
Grass lands & 3.0 \\
Heath lands & $3.0-6.0$ \\
\hline Other impacts on forests: & \\
Nutrient imbalances & $0.2-0.4$ \\
Elevated nitrogen leaching / N saturation & 1.0 \\
Fine root biomass / root length & $1.0-3.0$ \\
Sensitivity to frost and fungal diseases & $3.0-5.0$ \\
\hline
\end{tabular}

${ }^{1}$ Note that these values should be used with caution, e. g., in areas with high precipitation.

and temperate ecosystems are in the range of $0.1-$ $3.0 \mathrm{~kg} \mathrm{Nha}^{-1} \mathrm{yr}^{-1}\left(=7.1-214.3 \mathrm{eq} \mathrm{ha}^{-1} \mathrm{yr}^{-1}\right)$, where the higher values apply to wet(ter) soils; rates for welldrained soils are generally below $0.5 \mathrm{~kg} \mathrm{~N} \mathrm{ha}^{-1} \mathrm{yr}^{-1}$.

The long-term annual $\mathrm{N}$ immobilization of nitrogen was set to $0.2-0.5 \mathrm{~kg} \mathrm{~N} \mathrm{ha}^{-1} \mathrm{yr}^{-1}\left(14.3-35.71 \mathrm{eq} \mathrm{ha}^{-1}\right.$ $\times \mathrm{yr}^{-1}$ ). Considering that the immobilization of $\mathrm{N}$ is probably higher in warmer climates, values of up to $1 \mathrm{~kg} \mathrm{Nha}^{-1} \mathrm{yr}^{-1}$ (71.4 eq ha ${ }^{-1} \mathrm{yr}^{-1}$ ) could be used for $\mathrm{N}_{\mathrm{i}}$, without causing unsustainable accumulation of $\mathrm{N}$ in the soil.

Critical loads of $\mathrm{S}, \mathrm{CL}(\mathrm{S})$, and $\mathrm{N}, \mathrm{CL}(\mathrm{N})$, can be computed by defining a critical $\mathrm{ANC}$ leaching, $\mathrm{ANC}_{\mathrm{le}}$ :

$$
\begin{gathered}
\mathrm{CL}(\mathrm{S})+\mathrm{CL}(\mathrm{N})=\mathrm{BC}_{\mathrm{dep}}^{*}-\mathrm{Cl}_{\mathrm{dep}}^{*}+\mathrm{BC}_{\mathrm{w}}-\mathrm{BC}_{\mathrm{u}} \\
+\mathrm{N}_{\mathrm{i}}+\mathrm{N}_{\mathrm{u}}+\mathrm{N}_{\mathrm{de}}-\mathrm{ANC}_{\mathrm{le}, \text { rit }}
\end{gathered}
$$

where $\mathrm{BC}$ is the sum of base cations, where the subscripts $\mathrm{w}$ and $\mathrm{u}$ stand for weathering and net growth uptake, $\mathrm{ANC}_{\mathrm{le}, \text { crit }}$ is Acid Neutralizing Capacity.

Critical loads of sulphur and nitrogen, both contributing to acidification of ecosystems, and their exceedances were derived and mapped in a large-scale exercise for forest soils (deciduous, coniferous, and mixed forest), natural grassland, acidic fens, heath land, and mesotrophic peat bogs in Lithuania. Each ecosystem has its specific sensitivity against the air pollutants, which is expressed by the critical load value. To identify this, the geographical information from CORINE land cover database has to be overlapped with spatial information on soil and climate. In combination with the General Soil Map of Lithuania and climate data, conclusions on the vegetation structure of the land 


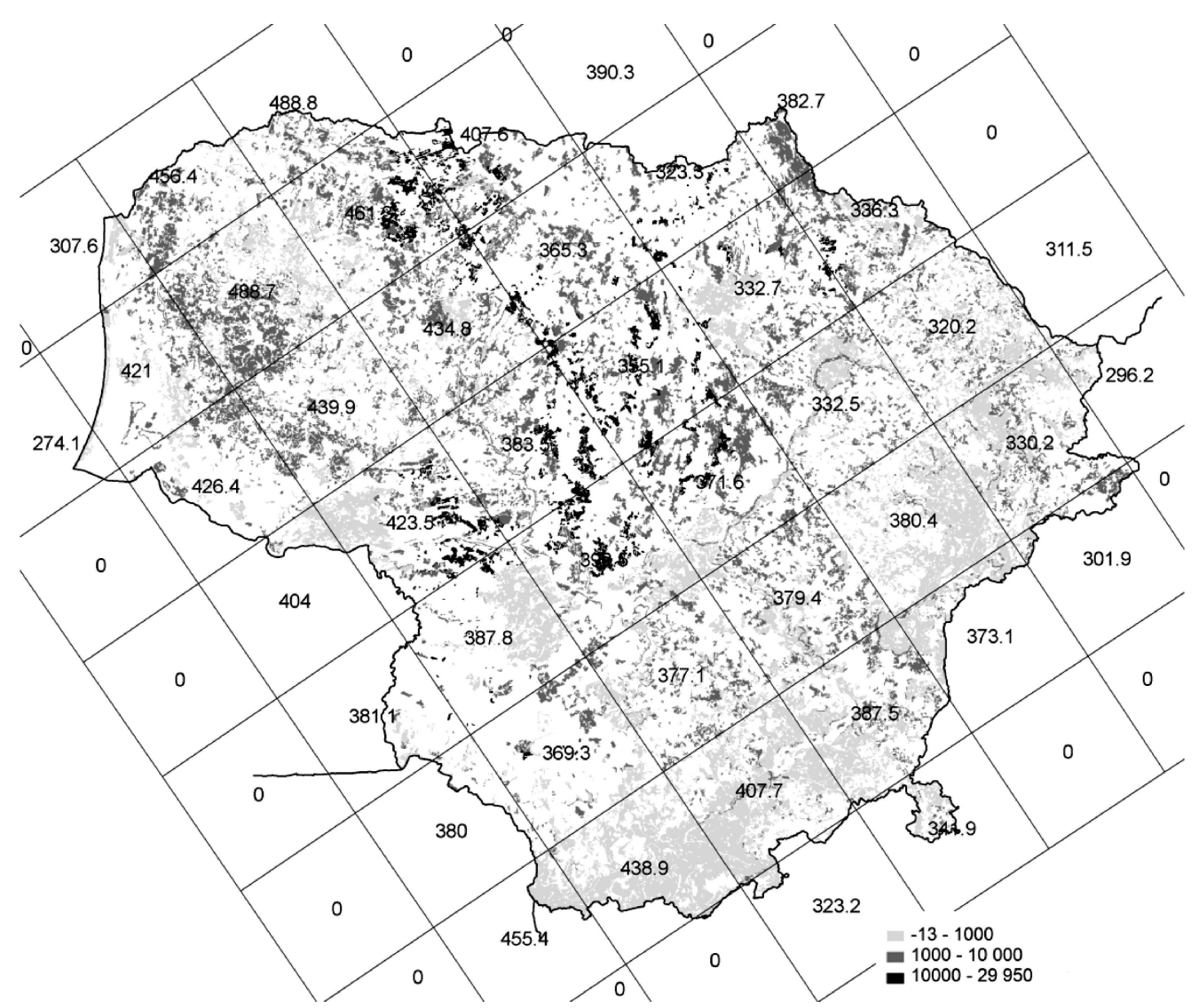

Fig. 2. Critical loads for oxidized nitrogen deposition and deposition values $\left(50 \times 50 \mathrm{~km}^{2}\right), \mathrm{eq} \mathrm{m}^{-2} \mathrm{yr}^{-1}$.

cover types can be drawn and the net biomass production can be derived.

The EMEP Eulerian acid deposition model output has been used as deposition of nitrogen and sulphur compounds in Lithuania.

Every year, emission data per sector from Lithuania to the LRTAP Convention were compiled at a national level and were reported through the EMEP programme. The emission data were reported in the Nomenclature For Reporting (NFR) source categories. There are 120 NFR categories in the reporting templates, including both detailed categories to facilitate reporting under the Convention. The national inventory is based on national statistics and country specific, technology dependent emission factors according to the EMEP/CORINAIR Emission Inventory Guidebook. In addition, new routines and standards for validating emission data have recently been adopted [15]. The background data (activity data and emission factors) for estimation of the Lithuanian emission inventories are collected and stored in databases.

\section{Results}

\subsection{Emission of sulphur and nitrogen compounds}

To perform the emission inventory management and reliable data management, the data collecting and reporting requirements are needed. All emission inventory data are organized in the emission inventory database and managed by using the PostgreSQL database management system; all needed calculations and road transport emission modelling are performed using SQL scripts developed at the Institute of Physics (Lithuania).

Sulphur is mainly emitted as $\mathrm{SO}_{2}$ by fossil fuel combustion, accounting for $\mathrm{SO}_{2}$ of almost $60 \mathrm{Tg} \mathrm{S}$ per year on the global scale. Other important sources are industrial processes (11 $\mathrm{Tg} \mathrm{S}$ per year), land use and waste treatment $(\sim 2 \mathrm{Tg} \mathrm{S}$ per year). About $25 \mathrm{Tg} \mathrm{S}$ per year of $\mathrm{SO}_{2}$ is emitted by natural sources. The main $\mathrm{N}$ substances emitted by human activities are $\mathrm{NO}$ and $\mathrm{NO}_{2}$ (together denoted as $\mathrm{NO}_{x}$ ) and ammonia $\left(\mathrm{NH}_{3}\right)$. Global emissions of $\mathrm{NO}_{x}$ and $\mathrm{NH}_{3}$ amount to $44 \mathrm{Tg} \mathrm{N}$ per year. European anthropogenic emissions have been steadily decreasing over the last twenty-five years, amounting 


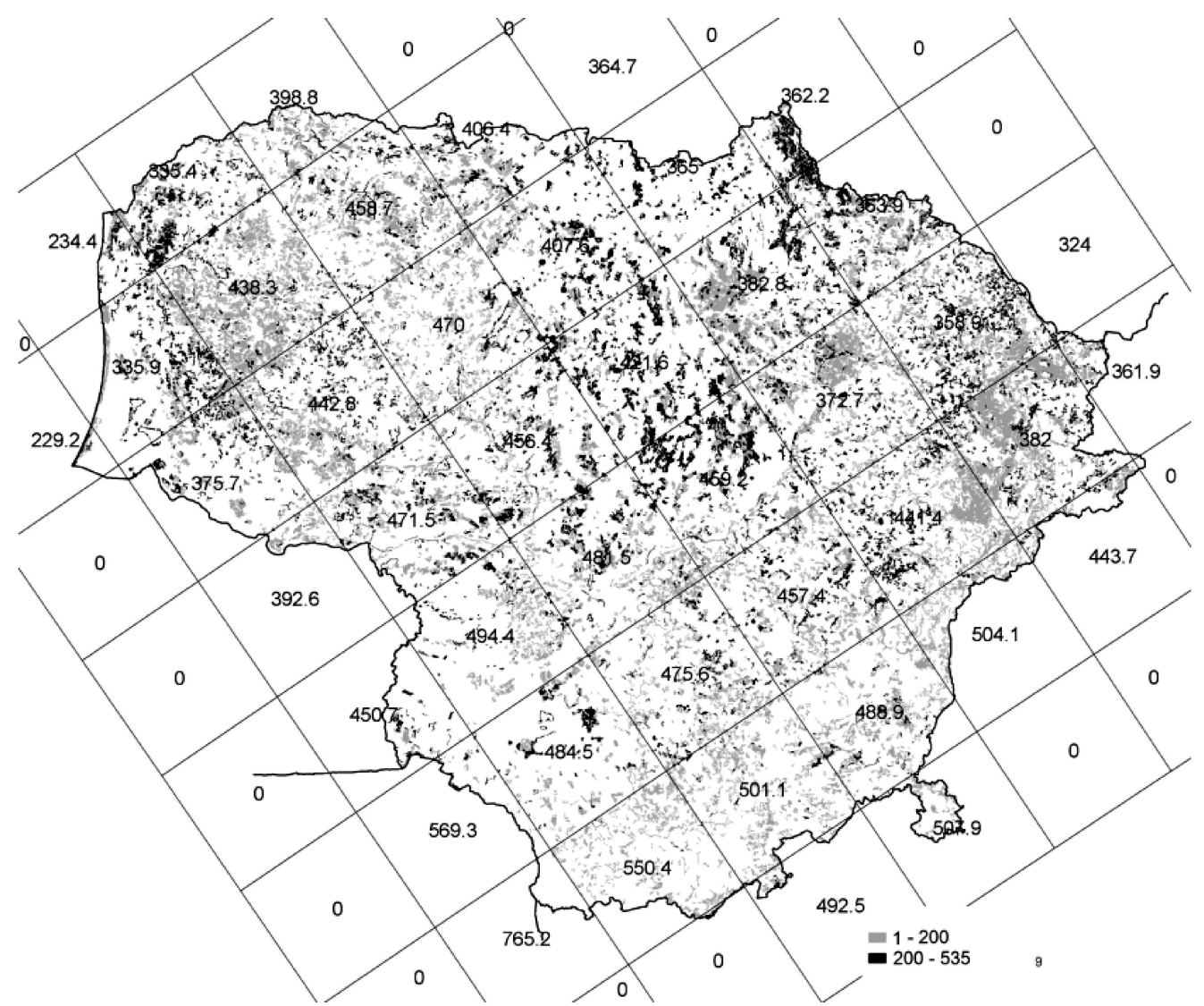

Fig. 3. Critical loads for reduced nitrogen deposition and deposition values $\left(50 \times 50 \mathrm{~km}^{2}\right), \mathrm{eq} \mathrm{m}^{-2} \mathrm{yr}^{-1}$.

from about $55 \mathrm{Tg}$ of $\mathrm{SO}_{2}$ in 1980 to $15 \mathrm{Tg}$ of $\mathrm{SO}_{2}$ in 2004. Across the EU-27, the largest reduction in emissions in percentage terms has been achieved for the acidifying pollutant $\mathrm{SO}_{2}$ : emissions in 2006 were almost 70\% less than in 1990 (Fig. 1).

The main part of the $\mathrm{SO}_{2}$ emission originates from combustion of fossil fuels, i. e. mainly coal and oil, in public power and district heating plants. A large reduction is largely due to installation of the desulphurization plant and use of fuels with lower content of sulphur in public power and district heating plants. Emissions of $\mathrm{SO}_{2}$ from the two most important key categories in the EU-27 decreased between 2001 and 2006. $\mathrm{SO}_{2}$ emissions from public electricity and heat production, which accounts for more than $58 \%$ of total $\mathrm{SO}_{2}$ emissions, decreased by $20 \%$ between 1990 and 2006 . The largest sources of emissions of $\mathrm{NO}_{x}$ are other mobile sources followed by road transport and combustion in energy industries (mainly public power and district heating plants). The emissions of $\mathrm{NO}_{x}$ from transport sector decreased from $42 \%$ in 2006 to $35 \%$ in the EU-27 [16].

It is well known that the sulphur components can be transported over long distances, thus the validation of emission trends cannot be judged by comparing mea- surements in a region with local emissions. Moreover, the processes that determine the distribution between the different sulphur components (sulphur dioxide, sulphate, and the amount of sulphur deposited dry and wet) may change depending on the chemical composition of the atmosphere as well as meteorological situation. Presently, larger proportions of $\mathrm{SO}_{2}$ are converted to sulphate. This has led to a smaller decrease in sulphate concentrations than in $\mathrm{SO}_{2}$ emissions. Moreover, whilst $\mathrm{SO}_{2}$ emissions have decreased dramatically, ammonia emissions have remained at the same level [17]. As a result, dry deposition of $\mathrm{SO}_{2}$ has become more efficient over the years, as the surface acidity to a large extent governs the resistance to dry deposition [18].

\subsection{Critical loads and exceedances for ecosystems}

Through the Convention on Long-Range Transboundary Pollution, member countries of the United Nations Economic Commission for Europe agreed that the critical loads approach provided an effective scientific approach for devising strategies for the abatement of acid deposition. The "critical load" approach was used to describe the vulnerability of ecosystems to deposition of $\mathrm{N}$ and $\mathrm{S}$ [19]. 


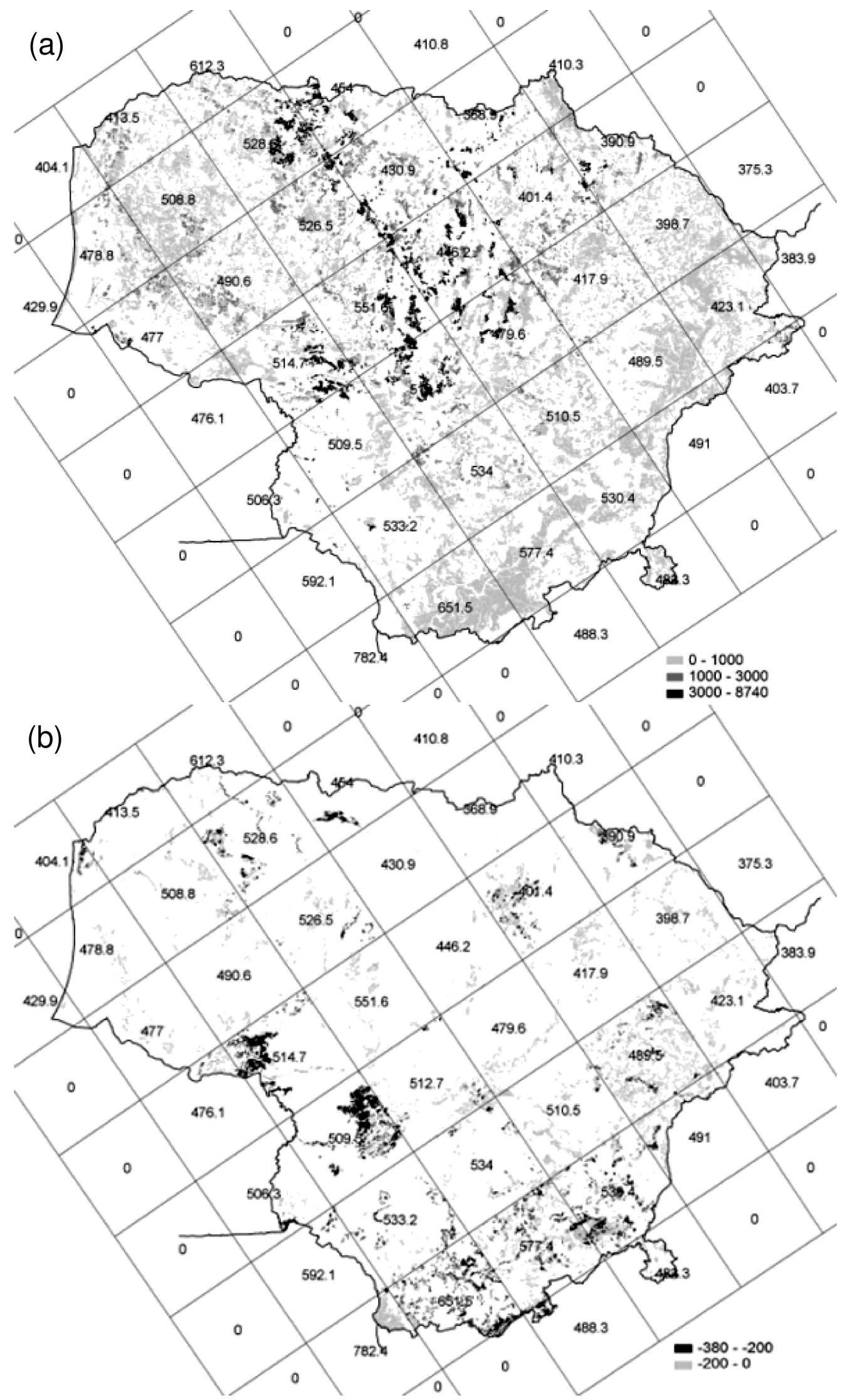

Fig. 4. (a) Critical loads for sulphur deposition, (a, b) deposition values $\left(50 \times 50 \mathrm{~km}^{2}\right)$, and (b) their exceedance, $\mathrm{eq} \mathrm{m}^{-2} \mathrm{yr}^{-1}$. 
The decrease in sulphur emissions over the past 16 years resulted in a reduced exceedance of critical loads for acid deposition. In the same period the reduction in the emissions of nitrogen oxides and ammonia remained not so significant. Therefore, emissions of sulphur and nitrogen compounds have become relatively more important and will continue to threaten the ecosystem function and stability. Recovery from pollutant stress will often be very slow and may sometimes even take hundreds of years, the risk of environmental damage remains at an unacceptable level.

Deposition of reduced and oxidized nitrogen and sulphur shows marked spatial patterns across Lithuania. Maps of annual atmospheric deposition of nitrogen and sulphur compounds have been compared with those of critical loads, and maps of exceedances of critical loads for sulphur and nitrogen compounds were developed (Figs. 2-4).

As Figs. 2-3 show, oxidized $\mathrm{N}$ critical loads have been exceeded slightly in the southern part of Lithuania, while the plots with the lowest oxidized $\mathrm{N}$ critical loads are situated in areas of central Lithuania. Deposition of oxidized $\mathrm{N}$ ranges from 0 to $488 \mathrm{eq} \mathrm{m}^{-2} \mathrm{yr}^{-1}$ (536 eq $\mathrm{m}^{-2} \mathrm{yr}^{-1}$ in 2000). Plots with the highest deposition ranging from 439 to $488 \mathrm{eq} \mathrm{m}^{-2} \mathrm{yr}^{-1}$ are particularly frequent in north-western Lithuania, while reduced nitrogen deposition is prevailing in the southern part. Temporal variation of deposition revealed a yearby-year decrease for N. From 2000 to 2006 deposition slightly decreased from 325 to $320 \mathrm{eq} \mathrm{m}^{-2} \mathrm{yr}^{-1}$.

Similarly, plots with lowest difference between reduced $\mathrm{N}$ critical loads and deposition are located mainly in central Lithuania. However, the highest ratio between critical loads and nitrogen deposition was registered in the southern, southeastern, southwestern, and central parts of Lithuania $\left(630 \mathrm{eq} \mathrm{m}^{-2} \mathrm{yr}^{-1}\right)$. The exceedance of reduced nitrogen critical loads for ecosystems was not registered.

Figure 4(b) shows that terrestrial ecosystems located in the southern and northeastern parts of Lithuania are the most sensitive to atmospheric deposition of acidifying sulphur compounds. The highest deposition was calculated for southern Lithuania (765 eq $\mathrm{m}^{-2} \mathrm{yr}^{-1}$ in 2000, $707 \mathrm{eq} \mathrm{m}^{-2} \mathrm{yr}^{-1}$ in 2006), while the lowest one was for the central part.

It has been found that at present the atmospheric deposition of nitrogen compounds causes smaller ecological problems than that of sulphur compounds (Figs. 24). It was found that values of atmospheric deposition of sulphur were high and exceeded the values of $\mathrm{CL}(\mathrm{S})$ in southwestern part of Lithuania $\left(812 \mathrm{eq} \mathrm{m}^{-2}\right.$ $\times \mathrm{yr}^{-1}$ in 2000, $782 \mathrm{eq} \mathrm{m}^{-2} \mathrm{yr}^{-1}$ in 2006). Such distribution of annual deposition was formed mostly by long-range air mass transport from Belarus and Poland and north-western Lithuania (737 eq $\mathrm{m}^{-2} \mathrm{yr}^{-1}$ in 2000, $612 \mathrm{eq} \mathrm{m}^{-2} \mathrm{yr}^{-1}$ in 2006), where oxidized sulphur deposition was caused by "Mažeikiu nafta" oil company. Like the nitrogen compounds, throughfall of $S$ is particularly low in northern and central Lithuania

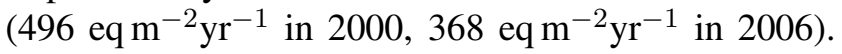
From 2000 to 2006 the total amount of sulphur flux decreased 1.2 times.

\section{Conclusions}

Critical loads for reduced sulphur were found to be exceeded in southwestern, southern, and northeastern areas of natural ecosystems (812 eq m $\mathrm{m}^{-2} \mathrm{yr}^{-1}$ in 2000 , $782 \mathrm{eq} \mathrm{m}^{-2} \mathrm{yr}^{-1}$ in 2006). The terrestrial ecosystems located in the southern and northeastern parts of Lithuania are the most sensitive to atmospheric deposition of acidifying sulphur compounds. The highest deposition was calculated for southern Lithuania (765 eq m $\mathrm{m}^{-2} \mathrm{yr}^{-1}$ in 2000, $707 \mathrm{eq} \mathrm{m}^{-2} \mathrm{yr}^{-1}$ in 2006), while the lowest for the central part. The lowest difference between reduced $\mathrm{N}$ critical loads and deposition was determined mainly for central Lithuania. However, the highest ratio between critical loads and nitrogen deposition was registered in the southern, southeastern, southwestern, and central parts of Lithuania $\left(630 \mathrm{eq} \mathrm{m}^{-2} \mathrm{yr}^{-1}\right)$. The exceedance of reduced nitrogen critical loads for ecosystems was not registered.

The critical load concept is widely used as a tool for developing emission control policies in Europe. The mapping of critical loads and exeedances for sulphur and nitrogen to Lithuanian terrestrial ecosystems was performed to define most sensitive terrestrial ecosystems and provide a quantative information as the basis of assessing if the strategies of emission reduction for nitrogen and sulphur are successful.

\section{Acknowledgements}

The research was supported by the Lithuanian State Science and Studies Foundation (project No. M-12/08) and Ministry of Environment.

\section{References}

[1] Convention on Long-Range Transboundary Air Pollution (Geneva Convention). http://www.unece.org/env/ lrtap/full\%20text/1979.CLRTAP.e.pdf. 
[2] Directive 2001/81/ec of the European Parliament and of the Council of 23 October 2001 on National Emission Ceilings for Certain Atmospheric Pollutants. http://eur-lex.europa.eu/LexUriServ/LexUri Serv.do?uri=OJ:L:2001:309:0022:0030:EN:PDF

[3] D. Simpson, W. Winiwarter, G. Börjesson, S. Cinderby, A. Ferreiro, A. Guenther, C.N. Hewitt, R. Janson, M.A.K. Khalil, S. Owen, T.E. Pierce, H. Puxbaum, M. Shearer, U. Skiba, R. Steinbrecher, L. Tarrason, and M.G. Öquist, Inventorying emissions from nature in Europe, J. Geophys. Res. 104(D7), 8113-8152 (1999).

[4] EMEP modelled air concentrations and depositions. http://webdab.emep.int/Unified_Model_Results/AN/.

[5] The World Health Report: Bridging the gaps (WHO, Geneva, 1995).

[6] J.L. Stoddard, D.S. Jeffries, A. Lukewille, T.A. Clair, P.J. Dillon, C.T. Driscoll, M. Forsius, M. Johannessen, J.S. Kahl, J.H. Kellog, A. Kemp, J. Mannio, D.T. Monteith, P.S. Murdoch, S. Patrick, A. Rebsdorf, B.L. Skjelkvale, M.P. Stainton, T. Traaen, H.van Dam, K. E. Webster, J. Wieting, and A. Wilander, Regional trends in aquatic recovery from acidification in North America and Europe, Nature 401, 575-578 (1999).

[7] W. Schoopp, M. Posch, S. Mylona, and M. Johansson, Long-term development of acid deposition (18802030) in sensitive freshwater regions in Europe, Hydrol. Earth Syst. Sci. 7, 436-446 (2003).

[8] G.W.J. van Lynden, European Soil Resources: Current Status of Soil Degradation, Causes, Impacts and Need for Action, Nature and Environment Report 71 (Council of Europe, Strasbourg, 1995).

[9] The Future of the Global Environment: A Modelbased Analysis Supporting UNEP's First Global Environment Outlook, eds. J. Bakkes and J. van Worden, UNEP/DEIA/TR.97-1 (RIVM, 1997).

[10] F. Dentener, J. Drevet, J.F. Lamarque, I. Bey, B. Eickhout, A.M. Fiore, D. Hauglustaine, L.W. Horowitz, M. Krol, U.C. Kulshrestha, M. Lawrence, C. GalyLacaux, S. Rast, D. Shindell, D. Stevenson, T. Van Noije, C. Atherton, N. Bell, D. Bergman, T. Butler, J. Cofala, B. Collins, R. Doherty, K. Ellingsen, J. Galloway, M. Gauss, V. Montanaro, J.F. Müller, G. Pitari, J. Rodriguez, M. Sanderson, F. Solmon, S. Strahan, M. Schultz, K. Sudo, S. Szopa, and O. Wild, Nitrogen and sulfur deposition on regional and global scales: A multimodel evaluation, Global Biogeochem. Cycles, 20, GB 4003, doi:10.1029/2005GB002672 (2006).
[11] W. de Vries, J. Kros, G.J. Reinds, W. Wamelink, H. van Dobben, R. Bobbink, B. Emmett, S. Smart, C. Evans, A. Schlutow, P. Kraft, S. Belyazid, H.U. Sverdrup,

A. van Hinsberg, M. Posch, and J.P. Hettelingh, Developments in modelling critical nitrogen loads for terrestrial ecosystems in Europe, Alterra Report 1382 (Wageningen, The Netherlands, 2007).

[12] W. de Vries, M. Posch, G.J. Reinds, and J. Kämäri, Critical loads and their exceedance on forest soils in Europe, Report 58, DLO Winand Staring Centre (Wageningen, The Netherlands, 1993).

[13] W. de Vries, G.J. Reinds, M. Posch, and J. Kamari, Simulation of soil response to acidic deposition scenarios in Europe. Water Air Soil Pollut. 78, 215-246 (1994).

[14] J.C. Dutch and P. Ineson, Denitrification of an upland forest site, Forestry 63 , 373-377 (1990).

[15] UNECE: Emission inventories and projections, progress report by the Co-Chairs of the Task Force, prepared in consultation with the secretariat. Annex III: Draft methods and procedures for the technical review of air pollutant emission inventories reported under the Convention and its protocols (EB.AIR/GE.1/2005/7, 2005). http://www.unece.org/ env/eb/welcome.html .

[16] EEA aggregated and gap-filled air emission dataset, based on 2008 officially reported national total and sectoral emissions to UNECE/EMEP Convention on Long-Range Transboundary Atmospheric Pollution. 2010 NEC Directive projections data: EEA Directive status report 2007, Technical report No. 9/2008 (EEA, 2007).

[17] V. Vestreng, E. Rigler, M. Adams, K. Kindbom, J.M. Pacyna, H. Denier van der Gon, S. Reis, and O. Travnikov, Inventory review 2006, Emission data reported to LRTAP and NEC Directive, Stage 1, 2 and 3 review and Evaluation of inventories of $H M$ and POPs, EMEP/MSC-W Technical Report 1/2006 (EMEP, 2006). http://www.emep.int .

[18] D. Fowler, M.A. Sutton, C. Flechard, J.N. Cape, R. Storeton-West, M. Coyle, and R.I. Smith, The control of $\mathrm{SO}_{2}$ dry deposition on natural surfaces by $\mathrm{NH}_{3}$ and its effect on regional deposition, Water Air Soil Pollut. 1, 39-48 (2001).

[19] H. Sverdrup and W. de Vries, Calculating critical loads for acidity with the simple mass balance method, Water Air Soil Pollut. 72, 143-162 (1994). 


\title{
SIEROS IR AZOTO JUNGINIŲ KRITINIŲ APKROVŲ LIETUVOS SAUSUMOS EKOSISTEMOMS IVERTINIMAS
}

\author{
V. Ulevičius, S. Byčenkienė, K. Senuta
}

Fizikos institutas, Vilnius, Lietuva

\section{Santrauka}

Pateikta kiekybinė sieros ir azoto junginių kritinių apkrovų Lietuvos ekosistemoms analizė. Ivertinant azoto junginiu kritines apkrovas mišku ekosistemoms naudotas masès balanso metodas, leidžiantis nustatyti rajonus, kur tos apkrovos yra viršytos. Kritiniu apkrovų koncepcija yra plačiai naudojama, ieškant palankaus susitarimo tarp gamtosaugininkų ir valdžios institucijų, priimančių sprendimus dèl teršalų emisijos apribojimų. Teršalų srautų i ekosistemas kiekis bei kritinių apkrovų Lietuvoje dydis nustatytas vado- vaujantis Tolimujų tarpvalstybinių oro teršalų pernašų konvencija. Apskaičiuotas oksiduotos sieros kritinių apkrovų bei bendro nusèdimo srauto skirtumas, kurio neigiamos reikšmès atspindi apkrovų viršijimus. Rasta, kad jos yra viršijamos pietų, pietryčių, pietvakarių bei kai kuriuose šiauriniuose Lietuvos regionuose. Mažiausios oksiduotos sieros, oksiduoto ir redukuoto azoto kritinių apkrovų bei bendro nusėdimo srauto skirtumo vertès nustatytos centriniame ir kai kuriuose šiauriniuose Lietuvos regionuose. 